\title{
錯体モデルを用いたアルカリ金属－黒鉛層間化 合物の密度沉関数法による解析
}

\section{A density functional theory study of the alkali metal graphite intercalation compounds using model complexes}

\author{
大嶋正人 **, 武田 馨*, 岡部裕介*, 松本里香**
}

Masato Oshima*,*, Kaoru Takeda*, Yusuke Okabe*, and Rika Matsumoto**

\begin{abstract}
To analyze the electronic state of alkaline metal-graphite intercalation compounds (AM-GIC), model complexes where two aromatic molecules coordinate to an alkaline metal center $(\mathrm{Li}, \mathrm{K}, \mathrm{Rb}$, and $\mathrm{Cs})$ were employed, and their geometry optimization, population analysis, and donor-accepter interaction analysis were performed using the density functional theory (DFT) with B3LYP level and Natural Bond Orbital (NBO). The distance of two aromatic ligands of each model complexes showed good agreement with the corresponding identity period of stage 1 AM-GIC. The electronic charges on alkali metal of model complexes and stabilization energies by electron donation from aromatic ligand to alkali metal were calculated by the population analysis.

The theoretical study of the mechanism of ethylene origomerization that proceeds inside the graphite layers was also carried out at DFT with B3LYP level. The Cs-C bond formation through the combination of two cationic $\mathrm{Cs}^{+}\left(\eta^{2}-\mathrm{H}_{2} \mathrm{C}=\mathrm{CH}_{2}\right)$ while accepting electrons from graphite layers is proposed as the initiation reaction of the origomerization. Additionally, we found that the carbon chain elongation reaction holds promise to proceed smoothly with a free energy of activation $\left(\Delta \mathrm{G}^{\ddagger}\right) 16.29[\mathrm{kcal} / \mathrm{mol}]$ under the presence of the chemical species having Cs-C bond.
\end{abstract}

KEYWORDS : Graphite, Intercalation, Computational chemistry, Reaction mechanism, Alkali metal

\section{1. はじめに}

黒鉛層間にはさまざまな化学種 (インターカレート)が挿入し, 数多くの黒鉛層間化合物 (Graphite Intercalation Compound : GIC) が報告されて抢り，それらの性質について詳細な研究が行 われている1)。しかし，その層間で進行する化学反応はエチレン やスチレンなどの不飽和炭化水素の重合反応2)-8) やベンゼンの 二量化6), 9) に限られており，またそれらの反応機構についての報告 例はほとんどない。これらの報告のうち, 高橋らによるセシウ ム一黒鉛層間化合物 (Cs-GIC) にエチレンを導入した三元系層間 化合物では, 層間内部でエチレンのオリゴメリ化が淮行し2)-6), 最 大 $\mathrm{C}_{20}$ 程度の炭化水素が生成していることが熱分析により確認さ れている10)。われわれは,一般にアルカリ金属もしくはアルカリ 金属のイオンとエチレンの接触のみではエチレンオリゴマーは得 られないことから，この反応は黒鉛層間の微小な,いわゆるナノ スペースでのみ進行する特異的な反応であることに着目した。黑 鉛層とインターカレートとの間では電子の授受が可能であり, 黒鉛 層が層間の反応に対して都合よく電子を収容したり，供給するバ
ッファとして機能し, 特異的な反応が進行するものと考えた。本 研究ではこの着想に基づき, 芳香族分子を配位子とするアルカリ 金属の錯体モデルを使ってアルカリ金属一黒鉛層間化合物 (AMGIC) の電子状態の解析を密度汎関数法により行った。また, エ チレンのオリゴメリ化反応についても解析を行い, 若干の知見を得 たので報告する。

\section{2. 計算方法}

\section{1 計算プログラム}

計算はプログラムパッケージとしてGaussian03, Rev D.0211) を用い, 反応基質, 生成物, 中間体および遷移状態の構造最適化, 振動, エネルギー, および電子密度計算は当該プログラムパッケ ージに含まれる密度汎関数法 12) を利用し, B3LYP13), 14) レベルで 行った。構造最適化計算は力の定数のマトリックス (Hessian Matrices）を逐次更新しながら行い, 原子間に働く力が最小とな り, 生成物および中間体では虚数振動が 0 に, 遷移状態では虚数 振動が 1 つになる構造を収束とした。基底関数は炭素および水素 には3-21 Gを用い, Li, K, Rb, CsにはLANL2DZ15)にdiffuse 関

* 東京工芸大学工学部ナノ化学科 : † 243-0297 神奈川県厚木市飯山 1583

* Department of Nanochemistry, Faculty of Engineering, Tokyo Polytechnic University : 1583 liyama, Atsugi, Kanagawa 243-0297, Japan

***東京工芸大学工学部基礎教育研究センター：テ243-0297 神奈川県厚木市飯山1583

** General Education and Research Center, Faculty of Engineering, Tokyo Polytechnic University : 1583 liyama, Atsugi, Kanagawa 243-0297, Japan 


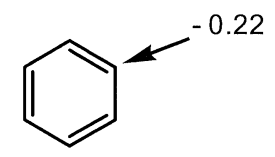

benzene (1)<smiles>COc1ccccc1CCc1ccccc1-c1ccccc1</smiles>

triphenylene (2)

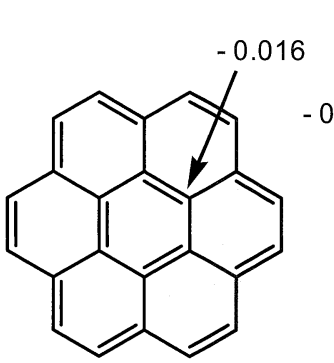

coronene (3)

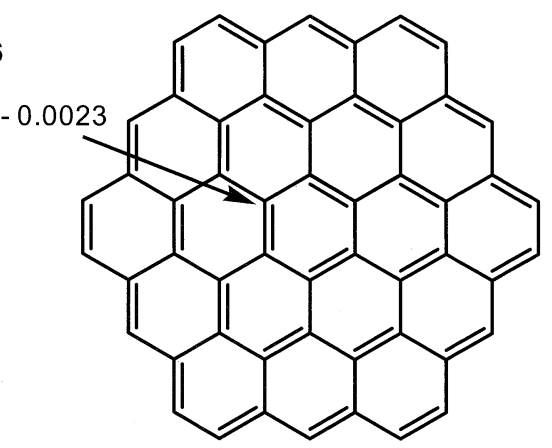

circumcoronene (4)
Fig.1 Model molecules of graphite layer. Negative numerical values indicate the average natural charge of central six carbons that were calculated by Natural Bond Orbital.

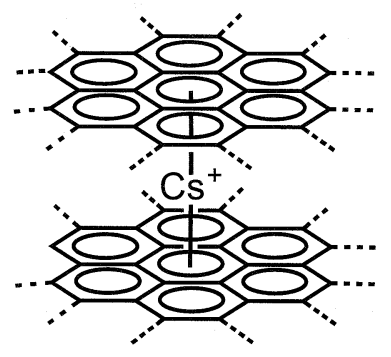

Fig.2 Structure of Cs-GIC model complex.

数16)を組み合わせて用いた。電荷はNatural Bond Orbital (NBO 5.G）プログラム 17),18)によって計算される Natural Charge を用い た。また, 芳香族配位子からアルカリ金属へのDonor-Accepter 相 互作用による安定化もNBOによって求めた。

\section{2 計算モデル}

本研究ではインターカレートしたアルカリ金属近傍の詳しい 情報を得ることやオリゴメリ化の反応機構の解析を目的として いるので, X $\alpha$ 法などで用いられている周期境界条件によらず, ア ルカリ金属を中心にして層間化合物の一部を切り出した構造に 相当するモデル錯体分子を設計し, その錯体分子を詳しく解析し た。黑鉛層のモデルとして Fig.1に示す芳香族分子 $1 \sim 4$ を検討 し,これらの構造を最適化して用いた。次に, Fig.2に示すように, 構造最適化した芳香族分子 $1 \sim 4$ をアルカリ金属に 2 分子配位さ せたモデル錯体分子をデザインし，この錯体分子を密度汎関数法 で解析した。

エチレンのオリゴメリ化反応は, (1)金属一炭素間の結合が形成 される開始反応, (2)炭素鎖が成長する成長反応, (3)炭素鎖の伸長 が止まる停止反応の3つを考慮する必要がある。これらのうち,

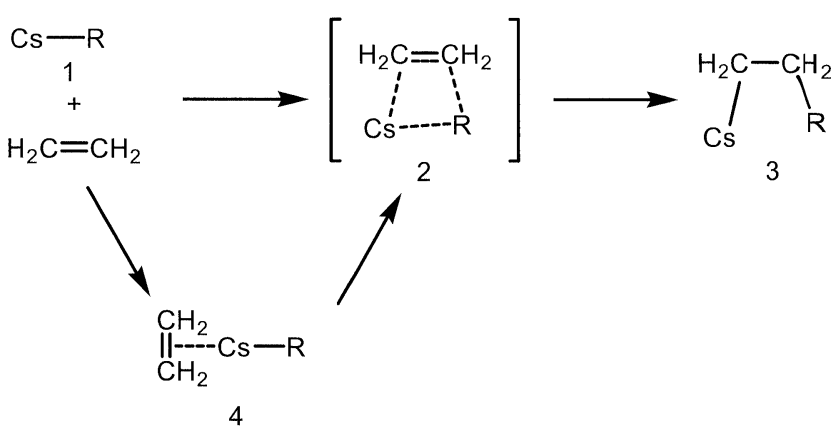

Scheme 1 Plausible mechanism of carbon chain elongation reaction.

停止反応は生成したエチレンオリゴマーのために層間が狭盆に なって停止すると考えられるので, 最初にセシウム一炭素結合が生 成する開始反応をこれまで知られているエチレンの重合反応を 基にいくつかのモデルを検証した。次に成長反応はScheme 1 に 示すようにセシウムー炭素結合を有する化学種 (1) がエチレン 分子に2のような遷移状態を経て付加反応して炭素鎖の伸長した 3 を生成する経路が考えられるほか, 遷移状態 2 の前に 1 にエチレ ンが配位した中間体 4 がいったん生成する経路が考えられる。本 研究ではセシウムー炭素結合を有する最小の化学種としてメチ ルセシウムを用い,これらの経路を検証した。

\section{3. 結果と考察}

\subsection{Cs-GIC モデル錯体の評価}

炭素層のモデルとなる芳香族分子 $1 \sim 4$ の構造最適化を行い, さらに中心部の六員環にあたる炭素上の電荷を計算した。水素 原子の電荷はおおむね+0.22であり, 同数の炭素原子からなるべ ンゼン $(\mathbf{1})$ の炭素の電荷は平均してー0.22であった。正電荷を 与える水素原子に対して炭素原子が多くなるほど, また水素原子 から離れるほど炭素原子の負電荷は減少し, トリフェニレン $(\mathbf{2})$, コロネン (3), サーカムコロネン $(\mathbf{4})$ ではそれぞれ-0.033,-0.016, - 0.0023 となった。

次に 1 ４ 2 分子配位子にもつセシウム錯体を設計し, 構造 最適化を行い，その構造を基にNatural Chargeを計算した。CsGIC は黒鉛にイオンではなく, 金属セシウムを導入して合成する ことから, モデル錯体全体の電荷は土0として計算した。

ベンゼンを配位子とする $\mathrm{Cs}\left(\eta^{6}-\mathrm{C}_{6} \mathrm{H}_{6}\right)_{2}(\mathbf{5})$ はさまざまな初期 構造からの計算を試みたが, ベンゼンが $\eta^{6}$ で配位する構造は得ら れず，いずれも Fig.3 (a) に示すように分離した。2つの芳香族配 位子はおおむね平行であることを想定していたが, 5 のベンゼン 配位子は大きく傾いていた。Table 1 に示すセシウム上の電荷も

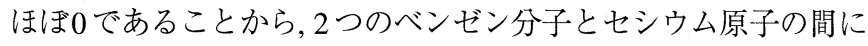
は大きな相互作用がないと考え，モデル錯体として不適当と結論 付けた。また, 本研究の計算条件では巨大な 4 を配位子とするセ シウム錯体の構造最適化は収束しなかった。

トリフェニレン $(\mathbf{2})$, コロネン $(\mathbf{3})$ を配位子にもつ Cs $\left(\eta^{6}-\mathrm{C}_{18} \mathrm{H}_{12}\right)_{2}$ (6), $\mathrm{Cs}\left(\eta^{6}-\mathrm{C}_{24} \mathrm{H}_{12}\right)_{2}(\mathbf{7})$ の構造を Figs.3 (b), (c) に示す。モデル 錯体6, 7 を配位子が重なる方向から見ると, いずれも2つの配位 
Table 1 Structural data and electrical charges of complex 5, 6, and 7.

\begin{tabular}{|c|c|c|c|c|}
\hline & $\mathrm{Cs}-\eta^{6}-\mathrm{C}_{6}[\AA]^{\mathrm{a}}$ & $\eta^{6}-\mathrm{C}_{6}-\mathrm{Cs}-\eta^{6}-\mathrm{C}_{6}\left[^{\circ}\right]$ & Electrical charge on cesium $^{\mathrm{b}}$ & ${\text { Average charge on } \eta^{6} \text {-carbons }}^{\mathrm{b}}$ \\
\hline $\mathrm{Cs}\left(\eta^{6}-\mathrm{C}_{6} \mathrm{H}_{6}\right)_{2}(\mathbf{5})$ & 3.897 & 107.8 & -0.018 & -0.25 \\
\hline $\mathrm{Cs}\left(\eta^{6}-\mathrm{C}_{18} \mathrm{H}_{12}\right)_{2}(\mathbf{6})$ & 3.251 & 173.9 & +0.95 & -0.075 \\
\hline $\mathrm{Cs}\left(\eta^{6}-\mathrm{C}_{24} \mathrm{H}_{12}\right)_{2}(\mathbf{7})$ & 3.252 & 180.0 & +0.96 & -0.038 \\
\hline
\end{tabular}

${ }^{a}$ Distances of cesium to aromatic ligand were calculated between centroid of six membered ring $\left(\eta^{6}-\mathrm{C}_{6}\right)$ and cesium atom.

${ }^{b}$ Electrical charges were calculated by NBO 5.G.

Table 2 Structural data and electrical charges for $M\left(\eta^{6}-\mathrm{C}_{24} \mathrm{H}_{12}\right)_{2}$.

\begin{tabular}{|c|c|c|c|}
\hline & $\begin{array}{c}\text { Interlayer distance of graphite } \\
\text { by experiment }[\AA]^{1,2)}\end{array}$ & $\begin{array}{c}\text { Distance between two } \\
\eta^{6}-\mathrm{C}_{24} \mathrm{H}_{12} \text { ligands }[\AA]\end{array}$ & $\begin{array}{c}\text { Electrical charge } \\
\text { on metal center }\end{array}$ \\
\hline $\mathrm{Li}\left(\eta^{6}-\mathrm{C}_{24} \mathrm{H}_{12}\right)_{2}(\mathbf{8})$ & 3.706 & 3.857 & +0.88 \\
\hline $\mathrm{K}\left(\eta^{6}-\mathrm{C}_{24} \mathrm{H}_{12}\right)_{2}(\mathbf{9})$ & 5.350 & 5.513 & +0.94 \\
\hline $\mathrm{Rb}\left(\eta^{6}-\mathrm{C}_{24} \mathrm{H}_{12}\right)_{2}(\mathbf{1 0})$ & 5.650 & 5.997 & +0.96 \\
\hline $\mathrm{Cs}\left(\eta^{6}-\mathrm{C}_{24} \mathrm{H}_{12}\right)_{2}(\mathbf{7})$ & 5.940 & 6.503 & +0.96 \\
\hline
\end{tabular}

Table 3 Population analysis and donor-acceptor interactions for $\mathrm{M}\left(\eta^{6}-\mathrm{C}_{24} \mathrm{H}_{12}\right)_{2}$.

\begin{tabular}{|c|c|c|c|c|c|}
\hline \multirow{2}{*}{ Model complexes } & \multicolumn{2}{|c|}{ Population analysis } & \multicolumn{2}{|c|}{$\begin{array}{c}\text { Total stabilization energy by the } \\
\text { donor-acceptor interaction }[\mathrm{kcal} / \mathrm{mol}]\end{array}$} & \multirow{2}{*}{$\begin{array}{c}\text { Ionic radius } \\
\text { (Atomic radius) } \\
(\AA)\end{array}$} \\
\hline & Valence & Rydberg & $\Delta \mathrm{E}_{\text {Inner }}$ & $\Delta \mathrm{E}_{\text {Outer }}$ & \\
\hline $\mathrm{Li}\left(\eta^{6}-\mathrm{C}_{24} \mathrm{H}_{12}\right)_{2}(\mathbf{8})$ & 0.06352 & 0.06000 & -20.48 & -23.13 & $0.60(1.52)$ \\
\hline $\mathrm{K}\left(\eta^{6}-\mathrm{C}_{24} \mathrm{H}_{12}\right)_{2}(\mathbf{9})$ & 0.03707 & 0.02929 & -6.59 & -16.16 & $1.33(2.27)$ \\
\hline $\mathrm{Rb}\left(\eta^{6}-\mathrm{C}_{24} \mathrm{H}_{12}\right)_{2}(\mathbf{1 0})$ & 0.02199 & 0.02342 & -3.13 & -6.77 & $1.49(2.47)$ \\
\hline $\mathrm{Cs}\left(\eta^{6}-\mathrm{C}_{24} \mathrm{H}_{12}\right)_{2}(7)$ & 0.01903 & 0.02050 & -2.26 & -6.16 & $1.67(2.65)$ \\
\hline
\end{tabular}

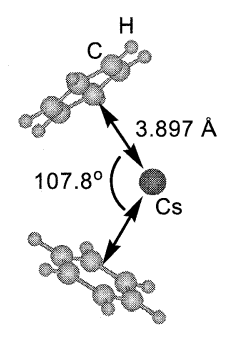

(a) $\left(\eta^{6}-\mathrm{C}_{6} \mathrm{H}_{6}\right)_{2} \mathrm{Cs}(5)$

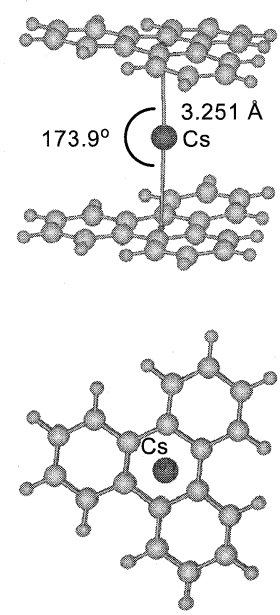

(b) $\left(\eta^{6}-\mathrm{C}_{18} \mathrm{H}_{12}\right)_{2} \mathrm{Cs}(6)$
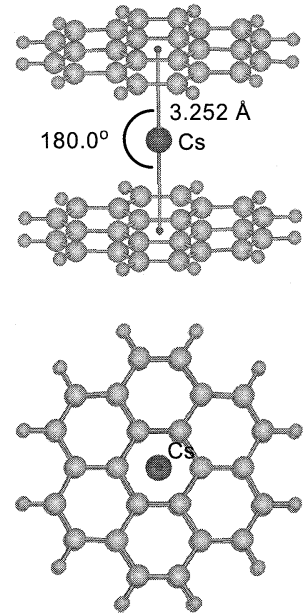

(c) $\left(\eta^{6}-\mathrm{C}_{24} \mathrm{H}_{12}\right)_{2} \mathrm{Cs}(7)$
Fig.3 The structure of model complexes 5, 6, and 7.

子は重なっており, 実際に観察されている構造と一致した1)。ま た, 6, 7 ではセシウムと芳香族配位子との距離はそれぞれ 3.251 , $3.252 \AA$ とほぼ同じ值になった。2つの配位子がやや傾いている 6では計算しにくいが, ほぼ平行になっている7では配位子間の 距離は $6.50 \AA$ となり,この距離がセシウムを挟んでいる黒鉛層間 に相当すると考えた。粉末 $\mathrm{X}$ 線法による $\mathrm{CsC}_{8}$ の繰り返し距離は $5.94 \AA$ であり, 計算值の $6.50 \AA$ は実測值より $9 \%$ 強長くなってい るが,ここで用いた計算条件では通常の有機分子でも結合距離は $2 \sim 5 \%$ 程度長めに出ること, 弱い相互作用の場合はもう少し長
めに出る傾向があることを考慮し, やや大きい誤差ではあるがモデ ル分子として許容であると考えた。

Table 1に示すように6および7ではセシウム上の電荷はいず れも+0.95程度となり, 黒鉛層間ではアルカリ金属は+1のイオン として観測されている実験事実と合致した。また, セシウムに配位 している炭素上の電荷は6,7でそれぞれー $0.075,-0.038$ となった。 組成が既知である $\mathrm{CsC}_{8} \sim \mathrm{CsC}_{24}$ のセシウム上の電荷を +0.95 程 度と仮定し, -0.95 の電荷が $8 \sim 24$ 個の炭素上に均等に分布す ると仮定すると, 炭素上の電荷はー0.12 - 0.04 程度と概算で きる。計算で得られた 6,7 の炭素上の電荷はいずれもこの範囲 に収まり,どちらもモデル分子として適当だと考えたが, 実際の エチレンのオリゴメリ化が報告されている $\mathrm{CsC}_{24}$ の炭素上の電荷 (ー0.0396)により近い值である 7 を最も適切なモデル錯体とし てさらに解析を進めることとした。

\section{2 モデル錯体を利用したAM-GICの解析}

コロネン $(\mathbf{3})$ を配位子とし, 中心金属をリチウム, カリウム, およ びルビジウムに変えたモデル錯体 $\mathrm{Li}\left(\eta^{6}-\mathrm{C}_{24} \mathrm{H}_{12}\right)_{2}(\mathbf{8}), \mathrm{K}\left(\eta^{6}-\right.$ $\left.\mathrm{C}_{24} \mathrm{H}_{12}\right)_{2}(\mathbf{9}), \mathrm{Rb}\left(\eta^{6}-\mathrm{C}_{24} \mathrm{H}_{12}\right)_{2}$ (10) の構造最適化を行った。ナト リウムを用いたモデル錯体の計算は結果を比較し得る十分な大き さの基底関数が見つからなかったため, 今回の報告からは除いた。 モデル錯体 8,9,10の構造最適化計算はいずれも2つのコロネ ン配位子がほぼ平行になるように収束したので, 黒鉛層間距離に 相当するコロネン配位子間の距離を読み取り, Table 2 に示した。 実験值と比べると計算值は $3 \sim 6 \%$ 程度大きな值になっている が, いずれも良い一致を示した。アルカリ金属上はセシウムのモデ 


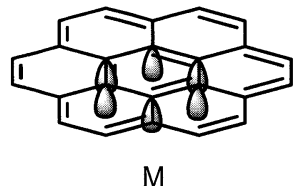

(a) (b)

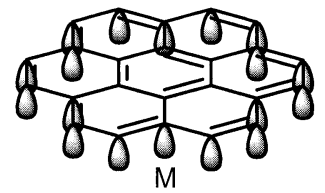

Fig.4 (a) Back donation from inner six carbons to alkali metal. (b) Back donation from outer eighteen carbons to alkali metal.

ルと同様に大きな正電荷があり,いずれもアルカリ金属は黒鉛層内 ではイオンとして存在している実験事実と合致する結果となっ た。正電荷の大きさはリチウムが最も小さく+0.88であったが, ほかはおおむね+0.95程度であった。

Table 3 にまとめた電子密度の解析ではV Valence 軌道と Rydberg 軌道に電子密度があることがわかった。これは黒鉛層からアル カリ金属への逆供与 (Back donation)によるものと考えられる。 イオン半径の小さなリチウムを中心金属にもつ 8 のV Valence 軌道, Rydberg 軌道にはともにほかの金属より大きな電子密度があり, 内側のV Valence 軌道のほうがRydberg 軌道よりやや電子密度が高 かった。カリウムを中心金属とする9も同様にValence 軌道のほ うが電子密度は高いが, イオン半径が大きいルビジウムやセシウム を有する10,7ではそれぞれの軌道の電子密度は同程度であった。

次に，逆供与による影響を調べるためにFig.4に示すようにク コロネン配位子を中央の6個の炭素 (inner) と外周に当たる18個 の炭素 (outer) に分け，それぞれの部分からのアルカリ金属への 電子供与による安定化を求めた。 $\Delta \mathrm{E}_{\text {Inner }}$ に示したものは中央の 6個の炭素の内核と六員環を形成する炭素一炭素間に帰属される 電子がアルカリ金属の空のValence およびRydberg 軌道へ供与され ることによる, いわゆる電子供与受容相互作用 (Donor-acceptor interaction）による安定化エネルギーを合計したもので, NBO プ ログラムによって求められる二次捸動解析 (SECOND ORDER PERTURBATION THEORY ANALYSIS OF FOCK MATRIX IN NBO BASIS) の項に出力される值から求めた。また, 外周の炭素 からの電子供与による安定化エネルギー $\left(\Delta \mathrm{E}_{\text {Outer }}\right)$ も同様にして 求めた。このとき, 中央の6つの炭素原子と外周の炭素原子との 結合間に帰属される電子による安定化エネルギーは $\Delta \mathrm{E}_{\text {Outer }}$ に含 めた。

$\Delta \mathrm{E}_{\text {Inner }}$ はモデル錯体 8 10, 7 の順にー20.48, - 6.59, - 3.13, $-2.26[\mathrm{kcal} / \mathrm{mol}]$ と小さくなり,イオン半径が大きくなるほど金 属と黒鉛層間の相互作用が小さくなることが示された。この傾 向は $\Delta \mathrm{E}_{\text {Outer }}$ でも同様である。比較のために, Fellerらによる, $\mathrm{M}^{+}$ $\left(\eta^{6}-\mathrm{C}_{6} \mathrm{H}_{6}\right)(\mathrm{M}=\mathrm{Li}, \mathrm{K}, \mathrm{Rb}$, and $\mathrm{Cs})$ におけるアルカリ金属のイオ ンとベンゼンとの間の実験および理論計算の結合エンタルピー をTable 4 に示した ${ }^{19)}$ 。実測のベンゼンとアルカリ金属のイオン との間の結合エンタルピーはイオン半径が大きくなるにつれて小 さくなり, 金属一黒鉛層間の相互作用が小さくなる傾向が示され ている。Fellerらの実測のCs $+\left(\eta^{6}-\mathrm{C}_{6} \mathrm{H}_{6}\right)$ の結合エンタルピーは $\mathrm{Li}^{+}\left(\eta^{6}-\mathrm{C}_{6} \mathrm{H}_{6}\right)$ の值と比べては $40 \%$ 程度しか小さくなっておら
Table 4 Experimental and theoretical binding enthalpies for $\mathrm{M}^{+}$ $\left(\eta^{6}-\mathrm{C}_{6} \mathrm{H}_{6}\right){ }^{19)}$

\begin{tabular}{|c|c|c|c|}
\hline \multirow{2}{*}{$\mathrm{M}^{+}\left(\eta^{6}-\mathrm{C}_{6} \mathrm{H}_{6}\right)$} & \multicolumn{3}{|c|}{ Binding enthalpies $(\mathrm{kcal} / \mathrm{mol})$} \\
\cline { 2 - 4 } & \multirow{2}{*}{ Experimental } & \multicolumn{2}{|c|}{ Theoretical } \\
\cline { 2 - 4 } & & $\mathrm{CCSD}(\mathrm{T})$ & DFT $(\mathrm{BP} 86)$ \\
\hline $\mathrm{Li}^{+}\left(\eta^{6}-\mathrm{C}_{6} \mathrm{H}_{6}\right)$ & $-39.3 \pm 3.2$ and -37.9 & $-36.8 \pm 0.2$ & -33.6 \\
\hline $\mathrm{K}^{+}\left(\eta^{6}-\mathrm{C}_{6} \mathrm{H}_{6}\right)$ & $-17.1 \pm 0.9$ and -19.2 & $-20.1 \pm 0.4$ & -13.0 \\
\hline $\mathrm{Rb}^{+}\left(\eta^{6}-\mathrm{C}_{6} \mathrm{H}_{6}\right)$ & $-16.4 \pm 0.9$ & $-16.4 \pm 0.2$ & -11.0 \\
\hline $\mathrm{Cs}^{+}\left(\eta^{6}-\mathrm{C}_{6} \mathrm{H}_{6}\right)$ & $-15.1 \pm 1.1$ & $-12.5 \pm 0.2$ & -9.0 \\
\hline
\end{tabular}

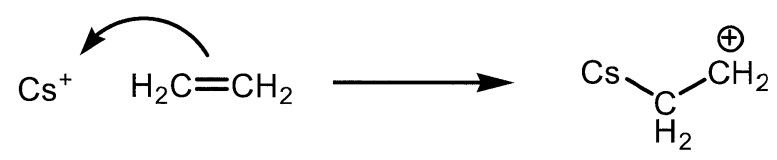

Eq.1

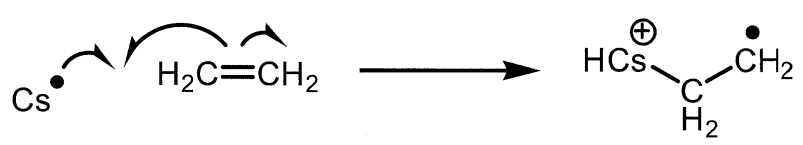

Eq.2

ず, 理論計算でも結合クラスター法 $(\operatorname{CCSD}(\mathrm{T}))$ ではそれはよく 再現されているが, 密度汎関数法 (DFT (BP86)) ではかなり小さ い值になることを併せて報告している。一般に密度汎関数法で は弱い相互作用は過小評価される傾向であることが原因だと考 えられ，われわれの電子供与受容相互作用の大きさが 7,10 の場 合に極端に小さくなるのは同様に密度汎関数法の特性によるた めと考えられる。

イオン半径の小さいリチウムでは $\Delta \mathrm{E}_{\text {Inner }}$ と $\Delta \mathrm{E}_{\text {Outer }}$ が同程度で, それぞれ20.48, $23.13[\mathrm{kcal} / \mathrm{mol}]$ と大きな值であるが, イオン半 径が大きくなると $\Delta \mathrm{E}_{\text {Outer }}$ による安定化エネルギーのほうが大き くなり,セシウムの場合では $\Delta \mathrm{E}_{\mathrm{Outer}}=-6.16[\mathrm{kcal} / \mathrm{mol}]$ は $\Delta \mathrm{E}_{\text {Inner }}=-2.26[\mathrm{kcal} / \mathrm{mol}]$ の 2.7 倍程度になることがわかった。 芳香環の6 員環の 1,4 位の炭素間の距離は $2.86 \AA$ 程度なので, カ リウム,ルビジウム, セシウムのV Valence, Rydberg 軌道はリチウ ムのそれに比べて中央の6 員環より外側に大きく広がっているた めと理解している。

\section{3 エチレンオリゴメリ化反応の解析}

最初にセシウムー炭素結合ができる開始反応について検討し た結果を述べる。なお，この検討に先立って微量の水分から生成 し得る $\mathrm{CsOH}$ のシウムー酸素結合にエチレンの挿入は起こら ず,オリゴメリ化にはセシウムー炭素結合を有する化学種が必須 であることをあらかじめ確認した。

Eq.1〜3 は既知のオレフィンの重合開始のステップを参考に セシウムとエチレンの組み合わせで描いたものである。Eq.1 は $\mathrm{Cs}+$ ヘのエチレンの $\pi$ 電子の攻撃により開始するカチオン重合, Eq.2 は中性のCs・とエチレンの間のラジカル重合, Eq.3 はコバル 卜などの遷移金属で見られるメタラシクロペンタンを形成する反 応である。構造最適化を行った結果, Eq.1, 2 は生成系側が大き 
く不安定化されて計算が収束しなかった。また, Eq.3 もセシウム の取り得る原子価が+1のみなので $\sigma$ 結合を 2 つ有する生成物に は無理があり，計算は収束しなかった。これらの予備的な検証か ら, セシウムは炭素との間に $\sigma$ 結合を 1 つしもてないこと, セシ ウムとエチレンからセシウムー炭素 $\sigma$ 結合が形成される際にセシ ウムと結合しないほうの炭素上にカチオンやラジカルができない ようにしないと安定な中間体が得られないことを確認したので, これらの要件を満たす開始反応として Eq.4に示すような2 分子 の $\mathrm{Cs}+\left(\eta^{2}-\mathrm{H}_{2} \mathrm{C}=\mathrm{CH}_{2}\right)(\mathbf{5})$ による経路を検討した。

2分子の5からなる原系の電荷は+2であり, この状態でセシウ ムー炭素結合, 炭素一炭素結合が形成される遷移状態を探索した が, 発見できなかった。そこで, 原系5に黒鉛層から 1 電子が供給 されたと仮定し, 全体の電荷を+1として遷移状態を探索したと ころ 286.0i の虚数振動を1つだけもつ構造6が収束した。

Fig.5に示す遷移状態6ではCs1-C1 間は3.2946 ̊̊なり, 5 の $3.7684 \AA$ よりも近づいていた。また, C1-C2 間は5 の $1.3356 \AA$ に 比べて $1.4297 \AA$ と伸びており, 分子間に当たるC2-C3 間は $2.1010 \AA$
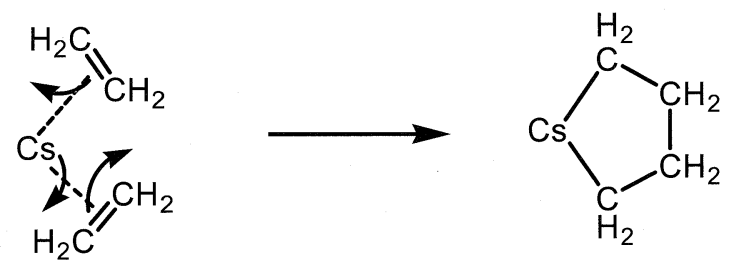

Eq.3

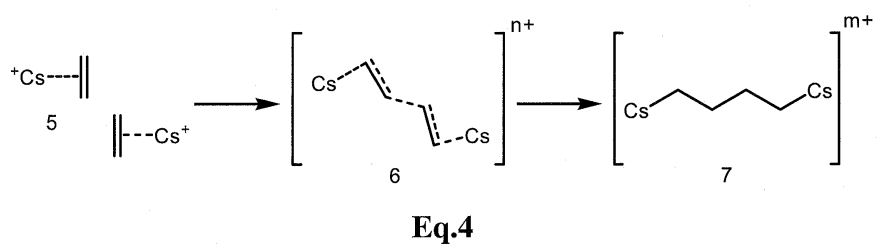

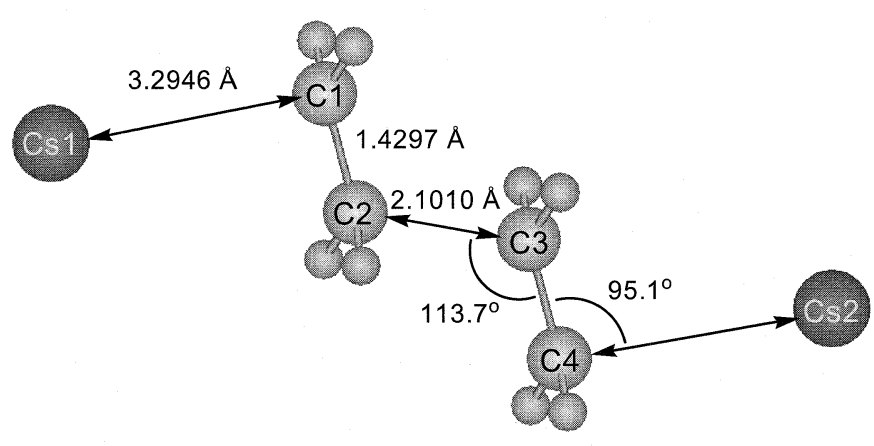

Fig.5 Structure of transition state 6.
に接近していた。8つの炭素一水素結合はいずれも,Cs1-C1, C2-C3, C4-Cs 間に結合が形成され, 各炭素原子周りの立体化学が $\mathrm{sp}^{2}$ か ら $\mathrm{sp}^{3}$ へ変化することに対応するように炭素一水素結合の向きが 変わっていることがわかった。Fig.6には286.0i の虚数振動に よる各原子の変位の方向をべクトルで眓示した。この図からも C2-C3 間の結合が形成される方向に炭素上のベクトルがあるこ と, セシウム上のベクトルは小さいが, $\mathrm{C} 1, \mathrm{C} 4$ に結合した水素原 子のベクトルはこれらの炭素の立体化学が $\mathrm{sp}^{2}$ から $\mathrm{sp}^{3}$ に変わる 方向に合致していることから遷移状態6はセシウムー炭素間の $\sigma$ 結合が形成される遷移状態として正しいことを確認した。

生成物 7 は全体の電荷を +1 とした $\mathbf{7 a}(\mathrm{m}+=1+)$ と中性の $\mathbf{7 b}(\mathrm{m}+=0)$ の計算が収束した。また, 2 分子の5 5 は合わせて +2 の電荷をもつので, 6 の前駆体として全体で+1の電荷をもつ $\left[\mathrm{Cs}\left(\eta^{2}-\mathrm{C}_{2} \mathrm{H}_{4}\right) \cdots \mathrm{Cs}\left(\eta^{2}-\mathrm{C}_{2} \mathrm{H}_{4}\right)\right]+\left(\mathbf{5}^{\prime}\right)$ のエネルギーを計算した。 それぞれの構造データと自由エネルギーの変化をTable 5 および

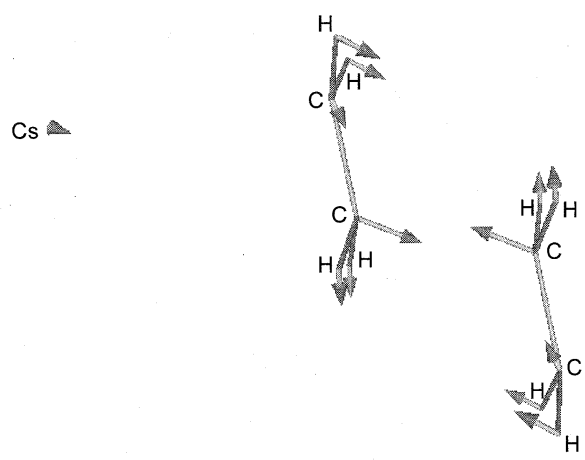

$\nabla \mathrm{Cs}$

Fig.6 The displacement vector of transition state 6 at 286.0i.

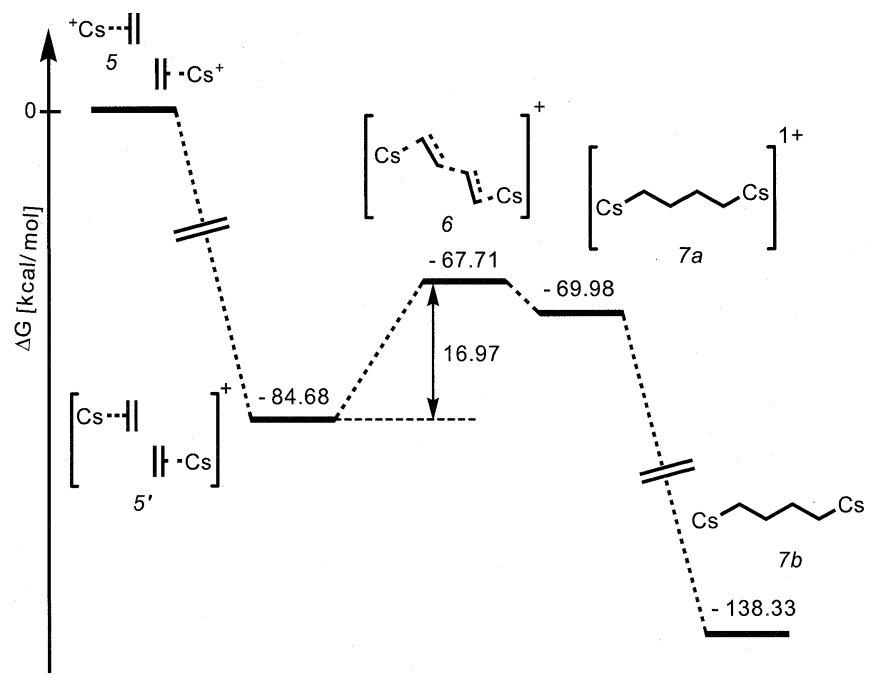

Fig.7 Energy diagram of $\mathrm{Cs}-\mathrm{C} \sigma$-bond formation reaction.

Table 5 Atomic distances, angles, and free energies of 5, 5', 6, 7a, and $\mathbf{7 b}$.

\begin{tabular}{|c|c|c|c|c|c|c|}
\hline & $\mathrm{Cs}-\mathrm{C} 1[\AA]$ & $\mathrm{C} 1-\mathrm{C} 2[\AA]$ & $\mathrm{C} 2-\mathrm{C} 3[\AA]$ & $\mathrm{Cs}-\mathrm{C} 1-\mathrm{C} 2\left[^{\circ}\right]$ & $\mathrm{C} 1-\mathrm{C} 2-\mathrm{C} 3\left[^{\circ}\right]$ & $\Delta \mathrm{G}[\mathrm{kcal} / \mathrm{mol}]$ \\
\hline $\mathbf{5}$ & 3.7684 & 1.3356 & - & 79.8 & - & 0 \\
\hline $\mathbf{5}$ & 4.1570 & 1.3509 & 3.4878 & 68.3 & 95.6 & -84.68 \\
\hline $\mathbf{6}$ & 3.2946 & 1.4297 & 2.1010 & 95.1 & 113.7 & -67.71 \\
\hline $\mathbf{7 a}$ & 3.2617 & 1.4953 & 1.6694 & 101.9 & 113.7 & -69.98 \\
\hline $\mathbf{7 b}$ & 3.2026 & 1.5289 & 1.5987 & 109.3 & 114.5 & -138.33 \\
\hline
\end{tabular}




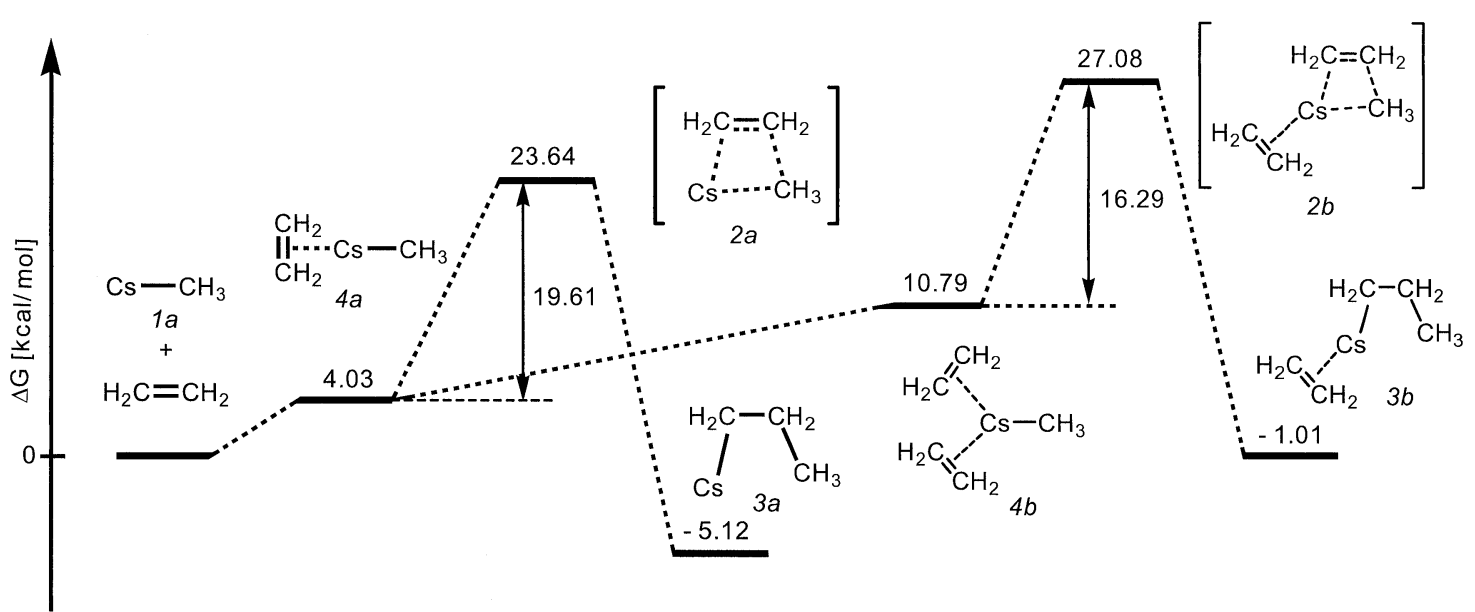

Fig.9 Energy diagram of ethylene insertion reaction to Cs-carbon bond.

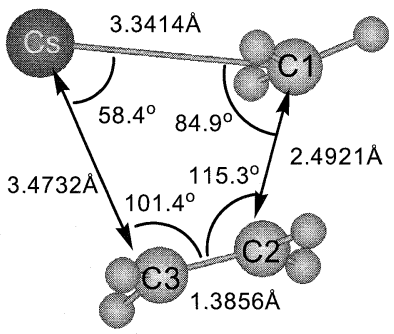

Fig.8 Structure of transition state 2a.

Fig.7に示す。2分子の5に1つ電子を加え, +1 の電荷をもつ5' は原系より $-84.68[\mathrm{kcal} / \mathrm{mol}]$ エネルギーの小さい状態となり， 5'から $16.97[\mathrm{kcal} / \mathrm{mol}]$ の活性化エネルギーで遷移状態6を経て Cs-CおよびC-C結合が形成された $\mathbf{7 a}$ を生成した。生成した $\mathbf{7 a}$ はさらに電子を 1 つ得て中性の安定な生成物 $7 \mathbf{b}$ となった。

以上に述べた原系5 から 6 を経て $7 \mathrm{~b}$ に至る反応は, 外部からの 電子の供給によりセシウムイオンとエチレンからセシウムー炭素 結合をもつ化学種が生成し得ることを示唆している。現在の計 算資源では黒鉛層に相当する芳香族分子を加えて検証すること はできないが, 冒頭で述べた「セシウムによるオリゴメリ化反応 が黒鉛層内でのみ進行する特異的な反応である」とする理由は, 反応時に必要な電子が黒鉛層から供給されていることだと結論 付けられる。

オリゴメリ化反応の炭素鎖の伸長反応は, 最も単純なセシウ ムー炭素結合を有する化学種としてメチルセシウム $\left(\mathbf{1 a}: \mathrm{R}=\mathrm{CH}_{3}\right)$ を用い, Scheme 1 に沿って検証した。構造最適化を行ったあと のセシウムー炭素距離は $3.1643 \AA$ となり, 実測されているセシウ ム一炭素 $\sigma$ 結合の距離が $3.1 〜 3.3 \AA$ であることから, おおむね実 験と合致する值であった。この1aがエチレンに付加する遷移状 態 $\mathbf{2 a}\left(\mathrm{R}=\mathrm{CH}_{3}\right)$ は, $411.3 \mathrm{i}$ の虚数振動を 1 つ有する構造に収束し, Fig.8に示すように 4 中心でセシウムと 3 個の炭素原子は同一平 面上に位置していることがわかった。生成物 $\mathrm{CsCH}_{2} \mathrm{CH}_{2} \mathrm{CH}_{3}(\mathbf{3 a}$ ： $\left.\mathrm{R}=\mathrm{CH}_{3}\right)$ および1aにエチレンが配位した中間体 $\left(\mathrm{C}_{2} \mathrm{H}_{4}\right) \mathrm{CsCH}_{3}$ $\left(\mathbf{4 a}: \mathrm{R}=\mathrm{CH}_{3}\right)$ についても構造最適化, 振動計算を行い, そのGibbs 自由エネルギーを基に算出したエネルギー図をFig.9に示した。

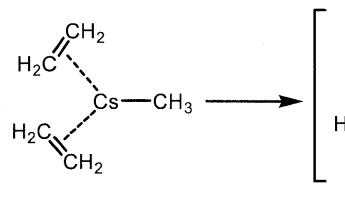

$4 b$<smiles>CCCSCCCCC1C=C[C@H]1C</smiles>

$2 b$

Eq.5

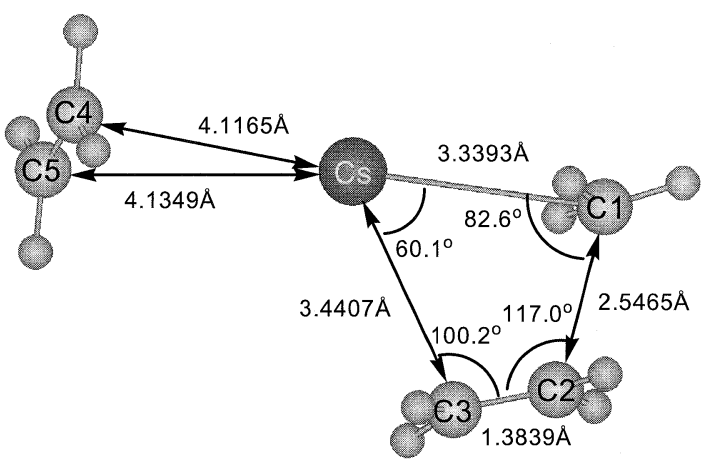

Fig.10 Structure of transition state $\mathbf{2 b}$. 原系の1a とエチレンとのエネルギーの和を 0 として相対的な エネルギーを求めたところ, $\Delta \mathrm{G}^{*}=23.64[\mathrm{kcal} / \mathrm{mol}]$ の活性化エ ネルギーで遷移状態 $\mathbf{2 a}$ を経て, 生成系である $\mathbf{3 a}$ が得られること がわかった。また，エチレンが1aに配位した中間体 $4 \mathbf{a}$ は原系よ り $4.03[\mathrm{kcal} / \mathrm{mol}]$ 高く, 4a からは $\Delta \mathrm{G}^{\ddagger}=19.61[\mathrm{kcal} / \mathrm{mol}]$ の活性 化エネルギーで $\mathbf{2 a}$ を経て $\mathbf{3 a}$ に至ることがわかった。

反応する際には黒鉛層内部には大過剩のエチレン分子が存在 するので, $\mathbf{4 a}$ にもう 1 分子のエチレンが配位した $\mathbf{4 b}$ から進行する 経路も考え得る (Eq.5)。検討の結果, Fig.10に示すような $310.6 \mathrm{i}$ の虚数振動を唯一もつ構造 $\mathbf{2 b}$ が見つかり, 虚数振動の方向から 正しい遷移状態であることを確認した。この経路のエネルギー もFig.9に併せて示してあり, $\Delta \mathrm{G}^{*}=16.29[\mathrm{kcal} / \mathrm{mol}]$ の活性化工 ネルギーで $\mathbf{4 b}$ から反応が進行することがわかった。以上の結果 から, これらの経路の活性化エネルギーはいずれも小さく, セシ ウムー炭素結合を有する化学種があれば炭素鎖の伸長反応が容 易に起こることがわかった。 


\section{4. まとめ}

以上述べたように, われわれは黒鉛層間で進行するエチレンの オリゴメリ化反応に注目し, 密度汎関数法を用いてその反応機構 を検討し, 次の知見を得た。

1)芳香族分子を黒鉛の代替えとし，それらを $2 つ$ 配位子にもつア ルカリ金属のモデル錯体の構造最適化を行って得られた構造 の 2 つ配位子間の距離が既知のステージ 1 の繰り返し距離と 良い相関を示すことがわかった。

2) モデル錯体の電子状態を解析し,アルカリ金属や配位子上の電 荷および黑鉛層からアルカリ金属への電子供与による安定化 エネルギーを求めた。

3) エチレンのオリゴメリ化反応について解析し, セシウムー炭素 $\sigma$ 結合を有する化学種からの炭素鎖の伸長反応は $\Delta \mathrm{G}^{\ddagger}=16.29$ [ $\mathrm{kcal} / \mathrm{mol}]$ の活性化エネルギーで容易に進行することがわか った。

4) セシウムー炭素 $\sigma$ 結合を有する化学種が形成される開始反応 として 2 分子の $\mathrm{Cs}+\left(\eta^{2}-\mathrm{C}_{2} \mathrm{H}_{4}\right)$ が黒鉛層から電子の供給を受け ながら中性の Cs- $\left(\mathrm{CH}_{2}\right)_{4}-\mathrm{Cs}$ を生成する機構を提案した。

5)「セシウムによるオリゴメリ化反応が黒鉛層内でのみ進行する 特異的な反応である」とする理由は, 反応時に必要な電子が黒 鉛層から供給され, セシウムの原子価 +1 が保持されることに よると結論付けた。

\section{謝 辞}

本研究を遂行するにあたり, 文部科学省学術フロンティア推進 事業「新しい分子機能の創出と計測一異方性場と水素結合相関の 高度利用」より研究費の援助を受けましたことに謝意を表します。

\section{文 献}

1) M. S. Dresselhaus and G. D. Dresselhaus, Advan. Phys. 30 (1981) 139-326.

2) Y. Takahashi, TANSO 1993 [No.160] 130-311 [in Japanese].

3) Y. Takahashi, K. Oi, T. Terai and N. Akuzawa, Carbon 29 (1991) 283-284.

4) H. Pilliere, Y. Takahashi, T. Yoneoka, T. Otosaka and N. Akuzawa, Synth. Met. 59 (1993) 191-199.
5) R. Matsumoto, Y. Takahashi and N. Akuzawa, Mol. Cryst. and Liq. Cryst. 340 (2000) 43-48.

6) R. Matsumoto, Y. Takahashi, K. Watanabe and N. Akuzawa, Synth. Met. 125 (2002) 141-146.

7) H. Shioyama, Carbon 35 (1997) 1664-1665.

8) H. Shioyama, Mol. Cryst. and Liq. Cryst. 340 (2000) 101-106.

9) S. Matsuzaki and M. Sano, Chem. Phys. Lett. 115 (1985) 424-425.

10) R. Matsumoto, T. Arii, Y. Oishi and Y. Takahashi, Thermochimica Acta 431 (2005) 53-57.

11) Gaussian 03, Revision D.02, M. J. Frisch, G. W. Trucks, H. B. Schlegel, G. E. Scuseria, M. A. Robb, J. R. Cheeseman, J. A. Montgomery, Jr., T. Vreven, K. N. Kudin, J. C. Burant, J. M. Millam, S. S. Iyengar, J. Tomasi, V. Barone, B. Mennucci, M. Cossi, G. Scalmani, N. Rega, G. A. Petersson, H. Nakatsuji, M. Hada, M. Ehara, K. Toyota, R. Fukuda, J. Hasegawa, M. Ishida, T. Nakajima, Y. Honda, O. Kitao, H. Nakai, M. Klene, X. Li, J. E. Knox, H. P. Hratchian, J. B. Cross, V. Bakken, C. Adamo, J. Jaramillo, R. Gomperts, R. E. Stratmann, O. Yazyev, A. J. Austin, R. Cammi, C. Pomelli, J. W. Ochterski, P. Y. Ayala, K. Morokuma, G. A. Voth, P. Salvador, J. J. Dannenberg, V. G. Zakrzewski, S. Dapprich, A. D. Daniels, M. C. Strain, O. Farkas, D. K. Malick, A. D. Rabuck, K. Raghavachari, J. B. Foresman, J. V. Ortiz, Q. Cui, A. G. Baboul, S. Clifford, J. Cioslowski, B. B. Stefanov, G. Liu, A. Liashenko, P. Piskorz, I. Komaromi, R. L. Martin, D. J. Fox, T. Keith, M. A. AlLaham, C. Y. Peng, A. Nanayakkara, M. Challacombe, P. M. W. Gill, B. Johnson, W. Chen, M. W. Wong, C. Gonzalez and J. A. Pople (2004) Gaussian, Inc., Wallingford CT.

12) A. D. Becke, J. Chem. Phys. 98 (1993) 5648-5652.

13) A. D. Becke, Phys. Rev. A38 (1988) 3098-3100.

14) C. Lee, W. Yang, R. G. Parr, Phys. Rev. B37 (1988) 785-789.

15) W. J. Pietro, M. M. Francl, W. J. Hehre, D. J. DeFrees, J. A. Pople and J. S. Binkley, J. Am. Chem. Soc. 104 (1982) 5039-5048.

16) Diffuse function for Li : Electronic Structure Theory, Vol.3, H. F. Schaefer III, Ed. (1977) Plenum Press. Diffuse function for K, Rb, and Cs : E. Glendening, D. Feller and M. Thompson J. Am. Chem. Soc. 116 (1994) 10657-10669.

17) F. Weinhold, in, A. G. Kutateladze (ed.), Computational Methods in Organic Photochemistry : Molecular and Supramolecular Photochemistry (2005), p.393, Taylor \& Francis/CRC Press, Boca Raton FL.

18） E. D. Glendening, J, K. Badenhoop, A. E. Reed, J. E. Carpenter, J. A. Bohmann, C. M. Morales and F. Weinhold, Theoretical Chemistry Institute, University of Wisconsin, Madison (2001).

19) D. Feller, D. A. Dixon and J. B. Nicholas, J. Phys. Chem. A 104 (2000) 11414-11419. 